\title{
Studi Awal Desain dan Pengujian Mesin Pengering Kerupuk Opak Sistem Pompa Kalor
}

\section{A Preliminary Study on Design and Testing of a Heat Pump Drying System for Opak Crackers}

\author{
H. Ambarita ${ }^{1 *}$, T. Sitepu ${ }^{1}$, E. Siahaan ${ }^{2}$, D.M. Nasution ${ }^{3}$ \\ ${ }^{1}$ Program Studi Teknik Mesin, Universitas Sumatera Utara \\ ${ }^{2}$ Program Studi Ilmu Manajemen, Universitas Sumatera Utara \\ ${ }^{3}$ Program Studi Teknik Mesin, Sekolah Tinggi Teknik Harapan \\ *Email: himsar@gmail.com
}

\begin{abstract}
Abstrak - Dalam tulisan ini, telah dilakukan sebuah studi awal mengenai desain dan pengujian mesin pengering sistem pompa kalor. Tujuannya untuk mendapatkan unjuk kerja mesin pengering dalam mengeringkan produk makanan berupa kerupuk opak. Ruang pengering berukuran $1200 \mathrm{~mm} \times 700 \mathrm{~mm} \times 888 \mathrm{~mm}$ dengan jumlah rak 10 diintegrasikan dengan unit pompa kalor. Pompa kalor yang digunakan beroperasi pada siklus kompresi uap dengan daya masukan $800 \mathrm{~W}$ dan fluida kerja refrigerant R22. Sampel kerupuk opak dengan berat awal $10 \mathrm{~kg}$ dikeringkan sebanyak tiga kali. Hasil pengujian diperoleh temperatur dan kelembaban udara ruang pengering masing-masing $57.5^{\circ} \mathrm{C}$ dan $45 \%$ pada laju aliran udara $0.24 \mathrm{~m} / \mathrm{s}$. Kinerja total dari mesin pengering diperoleh rata-rata 10,22. Kesimpulan utamanya bahwa sistem pengering pompa kalor dapat digunakan untuk mengeringkan kerupuk opak.
\end{abstract}

Kata kunci: pengering pompa kalor, unjuk kerja, kerupuk opak

Abstract - In this paper, a preliminary study on design and testing of a heat pump drying system has been carried out. The objective is to examine the performance of the dryer in the drying of food products such as opak crackers. A drying room with a dimension of $1200 \mathrm{~mm} \times 700 \mathrm{~mm} \times 888 \mathrm{~mm}$ with the number of tray 10 integrated with heat pump unit. The heat pump operated by vapor compression cycle with power input of $800 \mathrm{~W}$ and refrigerant $R 22$ as a working fluid. Samples of opak crackers with initial weight of $10 \mathrm{~kg}$ was dried for three times. The results show that the temperature and humidity of drying room is $57.5^{\circ} \mathrm{C}$ and $45 \%$ for air velocity $0.24 \mathrm{~m} / \mathrm{s}$, respectively. The average total performance of drying system is 10.22. The main conclusion can be drawn here is that the heat pump drying system can be used to dry the opak crackers.

Keywords: heat pump dryer, performance, opak crackers

\section{PENDAHULUAN}

Kombinasi teknologi pompa kalor dengan energi surya adalah konsep yang sangat menarik. Teknologi ini memiliki koefisien prestasi yang tinggi dan berpotensi memperbaiki kualitas produk yang dikeringkan. Beberapa penelitian mengenai pengering hibrida pompa kalor dan tenaga surya dapat ditemukan dalam literatur. Ronak Daghigh et al [1] melakukan ulasan mengenai sistem pengering hibrida pompa kalor dan tenaga surya untuk produk pertanian dan kelautan. Hasil dan observasi studi menunjukkan bahwa sistem pengering ini dapat meningkatkan kualitas produk, mengurangi konsumsi energi, dan meningkat koefisien prestasi serta efisiensi termal. Haifeng LI et al [2] melakukan studi mengenai sistem pengering hibrida pompa kalor dan tenaga surya untuk pengeringan biji-bijian di dalam gudang pengeringan. Hasil analisis menunjukkan bahwa fraksi tenaga surya dari unit pengering lebih tinggi 20\%, koefisien prestasi sistem $\left(\mathrm{COP}_{\mathrm{S}}\right)$ diperoleh 5.19, dan spesific moisture extraction rate (SMER) dapat mencapai $3.05 \mathrm{~kg} / \mathrm{kWh}$. Slim et al [3] mengevaluasi kinerja sebuah sistem pengeringan lumpur pada rumah kaca menggunakan pompa kalor dan tenaga surya yang diberi nama Solar and Heat Pump Sludge Drying System (S\&HPSDS). Prinsip model dibangun menggunakan hukum kekekalan massa, energi, momentum, serta korelasi perpindahan panas. Fokus studi mengarah pada kajian termo-ekonomi yang optimal dalam hal konsumsi energi. Fadhel et al [4] melakukan analisis performansi sebuah pengering hibrida pompa kalor kimia dan tenaga surya. Kinerja sistem telah dievaluasi pada kondisi cuaca di Malaysia. Sistem terdiri dari 4 komponen utama yaitu kolektor surya (tipe evacuated tube), tangki penyimpanan, unit pompa kalor gas-padatan, dan ruang pengering. Sebuah simulasi dibangun 
Ambarita, H. et al. Studi Awal Desain dan Pengujian Mesin Pengering Kerupuk Opak Sistem Pompa Kalor

untuk membandingkan hasil eksperimen dengan hasil simulasi. Hasil studi diperoleh efisiensi kolektor surya $80 \%$ untuk simulasi dan $74 \%$ untuk eksperimen. Nilai fraksi tenaga surya dari simulasi dan ekperimen masing-masing 0.795 dan 0.713, sedangkan COP diperoleh 2,2 untuk simulasi dan 2 untuk ekperimen. Hawlader et al [5] merancang dan menguji sistem pengering pompa kalor dan pemanas air sekaligus yang dibantu dengan tenaga surya. Kinerja sistem telah diteliti pada kondisi iklim di Singapura. Sistem terdiri dari kompresor, kolektor evaporator, tangki penyimpanan, kondensor, pemanas tambahan, blower, ruang pengering, dehumidifier, dan kolektor udara. Sebuah simulasi menggunakan bahasa Fortran dibangun untuk mengevaluasi kinerja sistem. Hasil menunjukkan bahwa nilai COP simulasi dengan eksperimen masing-masing 7.0 dan 5.0, sedangkan fraksi surya (SF) masing-masing $65 \%$ dan $61 \%$ untuk simulasi dan ekperimen. Ambarita et al [6] melaporkan studi mengenai performansi dan karakteristik pengering pakaian sistem pompa kalor. Parameter kinerja dibandingkan dengan sistem pengeringan pakaian menggunakan panas buangan dari kondensor AC (Waste heat of RAC). Hasil penelitian menunjukkan bahwa waktu pengeringan dan laju pengeringan dari pengering pompa kalor lebih cepat dibandingkan dengan sistem panas buangan dari AC.

Literatur di atas menunjukkan bahwa kombinasi pompa kalor dengan tenaga surya dilakukan untuk mendapatkan performansi sistem yang semakin baik dengan konsumsi energi yang semakin rendah dan kualitas produk yang tetap terjaga. Namun, untuk pengetahuan terbaik dari penulis, tidak ada studi dilaporkan berfokus pada aplikasi pompa kalor dengan tenaga surya untuk kasus Indonesia ditemukan dalam literatur. Dalam tulisan ini, telah dilakukan rancangbangun dan pengujian mesin pengering hibrida pompa kalor dan tenaga surya sebagai studi permulaan (preliminary study). Tujuan awalnya untuk mendapatkan performansi mesin pengering hibrida dalam mengeringkan produk hasil pertanian. Sampel yang diuji dipilih biji kakao karena secara konvensional dikeringkan dengan tenaga surya. Hasil penelitian diharapkan teknologi ini dapat diterapkan untuk proses pengeringan produk-produk pertanian maupun kelautan.

\section{METODE}

\section{A. Prinsip Kerja}

Pompa kalor (heat pump) merupakan perangkat yang sama dengan mesin pendingin (Refrigerator), perbedaannya hanya pada tujuan akhirnya. Mesin pendingin bertujuan menjaga ruangan pada suhu rendah dengan membuang panas dari ruangan. Sedangkan pompa kalor bertujuan menjaga ruangan berada pada suhu yang tinggi. Sama halnya dengan mesin pendingin, pompa kalor juga beroperasi menggunakan siklus kompresi uap (SKU) yang diilustrasikan melalui Diagram $p$ - $h$ pada Gambar 1. Komponen utamanya yaitu kompresor, kondensor, katup expansi, dan evaporator. SKU ideal terdiri dari 4 proses yaitu 1-2 disebut proses kompresi isentropis; 2-3 disebut proses kondensasi; 3-4 disebut proses ekspansi adiabatik; dan 4-1 disebut proses evaporasi isobarik.

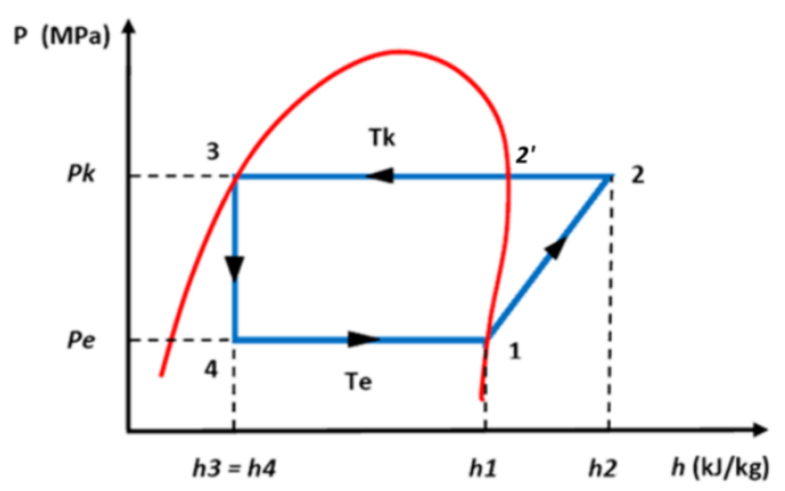

Gambar 1. Diagram $p-h$ SKU ideal

Daya kompresor dalam satuan $\mathrm{kJ} / \mathrm{s}$ dapat dihitung dengan persamaan (1) berikut ini.

$$
\mathrm{W}_{\mathrm{c}}=\dot{\mathrm{m}}_{\mathrm{ref}}\left(\mathrm{h}_{2}-\mathrm{h}_{1}\right)
$$

dimana $\dot{\mathrm{m}}_{\text {ref }}$ adalah laju aliran massa refrigeran $(\mathrm{kg} / \mathrm{s}), \mathrm{h}_{1}$ dan $\mathrm{h}_{2}$ masing-masing merupakan entalpi refrigeran saat masuk dan keluar kompresor dalam satuan $\mathrm{kJ} / \mathrm{kg}$. Jumlah kalor yang dilepas kondensor ke udara $(\mathrm{kJ} / \mathrm{s})$ dihitung dengan persamaan (2) atau persamaan (3).

$$
\begin{gathered}
\mathrm{Q}_{\mathrm{k}}=\dot{\mathrm{m}}_{\mathrm{ref}}\left(\mathrm{h}_{2}-\mathrm{h}_{3}\right) \\
\mathrm{Q}_{\mathrm{k}}=\dot{\mathrm{m}}_{\mathrm{air}} \mathrm{C}_{\mathrm{p}, \mathrm{air}}\left(\mathrm{T}_{\mathrm{o}, \text { air }}-\mathrm{T}_{\mathrm{i}, \text { air }}\right)
\end{gathered}
$$

$h_{3}$ yaitu entalpi refrigeran saat keluar kondensor (kJ/kg), $\dot{\mathrm{m}}_{\text {air }}$ adalah laju aliran massa udara yang melewati kondensor $(\mathrm{kg} / \mathrm{s}), \mathrm{C}_{\mathrm{p} \text {,air }}$ merupakan 
Ambarita, H. et al. Studi Awal Desain dan Pengujian Mesin Pengering Kerupuk Opak Sistem Pompa Kalor

kalor spesifik udara yang melewati kondensor $\left(\mathrm{kJ} / \mathrm{kg} .{ }^{\circ} \mathrm{C}\right)$, dan $\mathrm{T}_{\mathrm{i}, \text { air }}, \mathrm{T}_{\mathrm{o} \text {,air }}$ adalah temperatur udara saat masuk dan keluar kondensor. Jumlah kalor yang diserap evaporator $(\mathrm{kJ} / \mathrm{s})$ dihitung dengan persamaan (4).

$$
\mathrm{Q}_{\mathrm{e}}=\dot{\mathrm{m}}_{\mathrm{ref}}\left(\mathrm{h}_{1}-\mathrm{h}_{4}\right)
$$

Pengering pompa kalor telah dikenal sebagai usaha efisiensi energi ketika digunakan pada proses pengeringan. Keuntungan utama dari pengering pompa kalor berasal dari kemampuan pompa kalor dalam menghasilkan energi berguna dari panas buangan serta kemampuan untuk mengontrol temperatur dan kelembaban udara pengeringan [7]. Gambar 2 mengilustrasikan sebuah diagram skematis dari komponen SKU yang terintegrasi dengan ruang pengering (drying chamber). Udara pengeringan bergerak masuk melewati ruang pengering pada titik 1 dan menyerap kadar air dari produk yang dikeringkan. Udara yang mengandung kadar air tinggi pada titik 2 kemudian diarahkan melewati koil evaporator. Selama proses dehumidifikasi (menurunkan kelembaban) dari titik 2 ke titik 3, udara pengering pertama kali didinginkan secara sensibel sampai pada titik embunnya (dew point). Proses pendinginan akan menghasilkan kondensasi uap air yang terkandung di udara pengering.

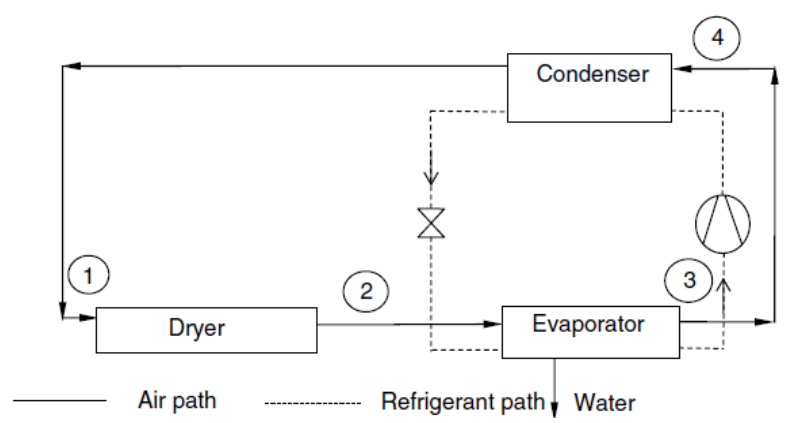

Gambar 2. Sistem pengering pompa kalor

Kalor laten penguapan kadar air kemudian diserap oleh evaporator untuk mendidihkan refrigeran. Kalor yang dipulihkan (recovery) akan dipompa ke kondensor. Udara yang didinginkan dan diturunkan kelembabannya selanjutnya akan menyerap kalor yang dilepas kondensor yang bergerak dari titik 4 ke titik 1 sebagai pemanasan sensibel untuk menaikkan temperatur udara pengering [8]. Kinerja sistem dinyatakan sebagai $\mathrm{COP}_{\mathrm{HP}}$ yang dihitung dengan persamaan (5)

$$
\mathrm{COP}_{\mathrm{HP}}=\frac{\mathrm{Q}_{\mathrm{k}}}{\mathrm{W}_{\mathrm{c}}+\mathrm{W}_{\mathrm{f}}}
$$

Jumlah panas yang diterima kolektor surya dihitung dengan persamaan (6) berikut ini.

$$
\mathrm{Q}_{\text {in }}=\mathrm{I} \cdot \mathrm{A} \cdot \tau \cdot \propto
$$

dimana I adalah intensitas radiasi matahari hasil perekaman alat ukur $\left(\mathrm{W} / \mathrm{m}^{2}\right)$, A4) stèbagai hluamerupakan ent penampang kolektor $\left(\mathrm{m}^{2}\right), \quad \tau$ sebagai transmisivitas polycarbonate, dan $\propto$ merupakan nilai absorbsivitas plat berwarna hitam (0.97).

\section{B. Set-up Eksperimen}

Dalam pelaksanaan eksperimen, telah didesain dan dipabrikasi sebuah mesin pengering hibrida pompa kalor-tenaga surya skala laboratorium. Komponen-komponen utamanya yaitu kolektor surya, kompresor, kondensor, katup ekspansi, evaporator, blower, dan ruang pengering. Pompa kalor yang diinstal beroperasi pada siklus kompresi uap dengan daya masukan 800W dan fluida kerja Refrigeran22. Blower yang digunakan memiliki daya $0,04 \mathrm{~kW}$. Ruang pengering berukuran $1200 \mathrm{~mm} \times 700 \mathrm{~mm} \times 888$ mm dengan jumlah rak 10 .

Sistem akuisisi data diinstal pada setup eksperimen sebagai alat pengukuran. Temperatur dan kelembaban udara pengeringan diukur menggunakan EL-USB data logger dengan akurasi $0.3^{\circ} \mathrm{C}$ dan $2 \% \mathrm{RH}$. Pengukuran temperatur dan kelembaban udara sebanyak 2 titik yaitu ruang pengering dan keluar evaporator. Pengukuran kecepatan udara pengeringan dilakukan pada saat udara melewati kondensor dengan menempatkan Anemometer tipe hot wire dengan akurasi $0.1 \mathrm{~m} / \mathrm{s}$. Untuk mengukur berat sampel yang dikeringkan digunakan Load cell tipe $S$ dengan akurasi 1.0 gram yang ditempatkan pada ruang pengering dan pengukuran tekanan kerja Refrigeran 22 menggunakan pressure gauge pada 3 titik pengukuran yaitu sisi isap kompresor, sisi tekan kompresor, dan sisi keluar kondensor. Temperatur kolektor, kondensor, dan evaporator diukur menggunakan Agilent 34972A dengan ketelitian $0.03^{\circ} \mathrm{C}$. Intensitas radiasi matahari diukur menggunakan Hobo Microstation Data Logger dengan akurasi 10.0 $\mathrm{W} / \mathrm{m}^{2}$. Arus kerja pompa kalor diukur menggunakan Digital clamp meter dengan akurasi 0.1A. Instalasi kelistrikan dikemas dalam sebuah kontrol panel yang juga dilengkapi pengukur tegangan listrik dan pressure switch sebagai pengontrol tekanan sistem, dan saklar untuk memudahkan pengoperasian. Gambar 3 
Ambarita, H. et al. Studi Awal Desain dan Pengujian Mesin Pengering Kerupuk Opak Sistem Pompa Kalor

menunjukkan desain, diagram skematis, dan akuisisi data pengukuran dari setup eksperimen.

\section{Metode Pengeringan}

Kerupuk opak yang dikeringkan sebanyak $10 \mathrm{~kg}$ untuk 1 sampel. Pengeringan dilakukan sebanyak 3 kali. Setiap sampel diukur beratnya pada kondisi kering dan basah. Rak di dalam ruang pengering berjumlah 10 , setiap 1 rak menampung $1 \mathrm{~kg}$ kerupuk opak basah, sehingga kapasitas total dalam satu siklus pengeringan berjumlah $10 \mathrm{~kg}$ kerupuk opak. Diperoleh waktu pengeringan rata-rata selama 150 menit hingga kerupuk opak kering. Sistem akuisisi data diatur untuk merekam pengukuran setiap 1 menit waktu pengeringan, sedangkan tekanan dan temperatur kerja Refrigerant 22 diamati secara visual setiap 2 menit waktu pengeringan. Pengeringan dianggap selesai jika berat sampel telah menunjukkan nilai berat pada kondisi kering. Berat akhir sampel rata-rata yang dihasilkan adalah $7,8 \mathrm{~kg}$.

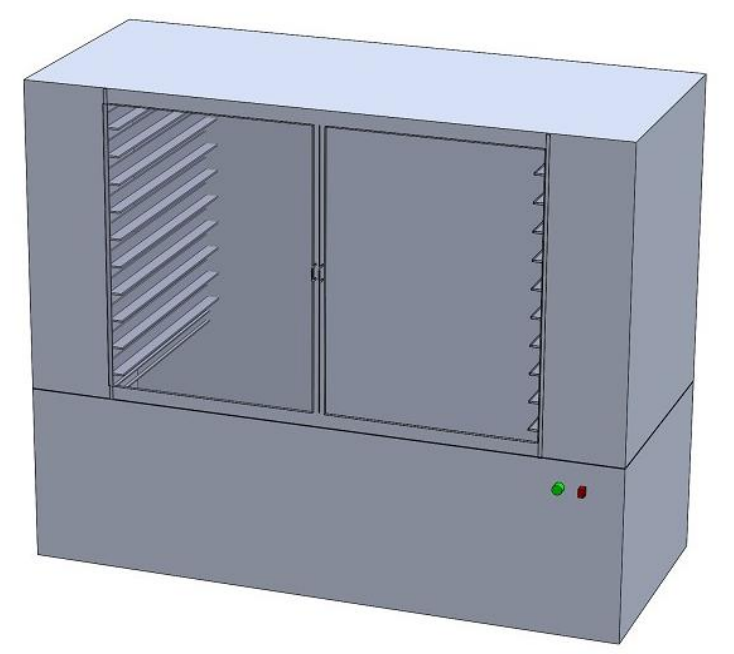

pada pengeringan sampel 3 yaitu $57.5^{\circ} \mathrm{C}$ dan $45 \%$.

Tabel 1. Temperatur dan RH ruang pengering

\begin{tabular}{|l|l|l|l|}
\hline Tanggal & Percobaan & $\begin{array}{l}\text { Temperatur } \\
\left({ }^{\mathbf{0}} \mathbf{C}\right)\end{array}$ & $\begin{array}{l}\text { RH } \\
(\mathbf{\%})\end{array}$ \\
\hline $05 / 11 / 16$ & Sampel 1 & 50.8 & 51 \\
\hline $06 / 11 / 16$ & Sampel 2 & 54.3 & 48 \\
\hline $07 / 11 / 16$ & Sampel 3 & 57.5 & 45 \\
\hline
\end{tabular}

Waktu pengeringan dapat dihemat $58,3 \%$ dari proses pengeringan dengan sinar matahari. Akan tetapi pengeringan konvensional tetap memiliki keunggulan hingga saat ini karena sumber panas yang gratis serta ketersediaan lahan mitra yang cukup luas untuk mengeringkan kerupuk opak dalam jumlah besar. Walaupun waktu pengeringan cukup lama namun tidak akan mempengaruhi jumlah omset yang diperoleh. IPTEK yang telah dihasilkan ini bersifat membantu proses pengeringan opak jika terjadi musim penghujan agar produktivitas tidak menurun secara drastis

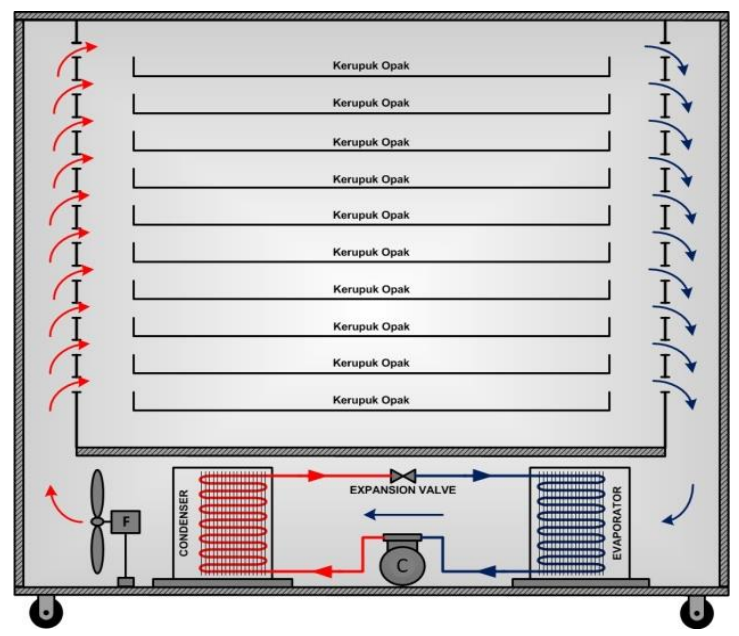

Gambar 3. Desain, diagram skematis, dan akuisisi data pengukuran

Jika dibandingkan dengan pengeringan langsung dengan sinar matahari, kerupuk opak membutuhkan waktu sekitar 6 jam atau 360 menit mulai dari pukul 09.00 hingga 15.00 sampai menjadi kering.

\section{HASIL DAN PEMBAHASAN}

Studi ini telah dilaksanakan pada bulan Nopember 2016 di Pusat Riset Sustainable Energy, Fakultas Teknik USU. Tabel 1 memperlihatkan hasil pengukuran temperatur dan kelembaban ruang pengering untuk ketiga sampel kerupuk opak. Nilai temperatur tertinggi dan kelembaban terendah ruang pengering diperoleh yang dapat mempengaruhi omset penjualan kerupuk opak.

Kinerja utama dari mesin pengering ini adalah kinerja total $\left(\mathrm{COP}_{\mathrm{HP}}\right)$. Kinerja total dapat meningkat jika kondensor mampu memanaskan udara pengering lebih banyak dengan konsumsi daya yang tetap. Dari hasil pengukuran dapat dihitung kinerja sistem menggunakan persamaan pompa kalor yang telah dijelaskan sebelumnya. Unjuk kerja tersebut diberikan pada Tabel 2. Dari ketiga proses pengeringan diperoleh nilai kinerja total pompa kalor rata-rata 10.2, yang berarti bahwa setiap $1 \mathrm{kWh}$ energi listrik yang 
Ambarita, H. et al. Studi Awal Desain dan Pengujian Mesin Pengering Kerupuk Opak Sistem Pompa Kalor

dibutuhkan mesin pengering dapat menghasilkan 10.2 kWh energi untuk memanaskan dan mendinginkan udara pengering.

Tabel 2. Koefisien prestasi mesin pengering

\begin{tabular}{|l|l|l|l|l|r|}
\hline Percobaan & $\begin{array}{l}\dot{\mathbf{m}}_{\text {udara }} \\
(\mathbf{k g} / \mathbf{s})\end{array}$ & $\begin{array}{c}\mathbf{Q}_{\mathbf{k}} \\
(\mathbf{k W})\end{array}$ & $\begin{array}{c}\mathbf{Q}_{\mathbf{e}} \\
(\mathbf{k W})\end{array}$ & $\begin{array}{c}\mathbf{W}_{\mathbf{c}} \\
(\mathbf{k W})\end{array}$ & $\mathbf{T P}$ \\
\hline Sampel 1 & 0.041 & 4.41 & 3.64 & 0.8 & 10.06 \\
\hline Sampel 2 & 0.062 & 4.30 & 3.56 & 0.8 & 9.82 \\
\hline Sampel 3 & 0.049 & 4.49 & 3.69 & 0.8 & 10.21 \\
\hline \multicolumn{6}{|c|}{ Rata-rata } \\
\hline
\end{tabular}

\section{KESIMPULAN}

Dari hasil pengujian mesin pengering kerupuk opak dapat dilihat bahwa untuk mengeringkan sampel dengan berat awal $10 \mathrm{~kg}$ hingga mencapai rata-rata $7.8 \mathrm{~kg}$ dibutuhkan waktu selama 150 menit. Jika dibandingkan dengan pengeringan langsung dengan sinar matahari, kerupuk opak membutuhkan waktu sekitar 6 jam atau 360 menit mulai dari pukul 09.00 hingga 15.00 sampai menjadi kering. Kesimpulan utama dari studi ini adalah bahwa mesin pengering pompa kalor yang telah dirancangbangun dapat digunakan untuk mengeringkan kerupuk opak dan dapat berfungsi dengan baik. Mesin pengering ini juga dapat diaplikasikan untuk pengeringan produk-produk pertanian lainnya yang bermutu tinggi.

\section{DAFTAR PUSTAKA}

[1] R. Daghigh, M.H. Ruslan, M.Y. Sulaiman, K. Sopian, Review of solar assisted heat pump drying systems for agricultural and marine products, Renewable and Sustainable Energy Reviews 14 (2010) 2564-2579.

[2] Haifeng LI, Yanjun DAI, Jianguo DAI, X. Wang, L. Wei, A solar assisted heat pump drying system for grain in-store drying, Energy Power Eng. 2010, 4(3) 386-391.

[3] R. Slim, A. Zoughaib, D. Clodic, Modeling of solar and heat pump sludge drying system, International Journal of Refrigeration 31 (2008) 1156-1168.

[4] M.I. Fadhel, K. Sopian, W.R.W. Daud, Performance analysis of solar-assisted chemical heat pump dryer, Solar Energy 84 (2010) 1920-1928.

[5] M.N.A. Hawlader, S.K. Chou, K.A. Jahangeer, S.M.A. Rahman, Eugene Lau K.W, Solar-assisted heat-pump dryer and water heater, Applied Energy 74 (2003) 185193.
[6] H. Ambarita, D.M. Nasution, S. Gunawan, A.H. Nasution, Performance and characteristic of heat pump clothes drier, IOP Conference Series, Materials Science and Engineering (2016).

[7] N. Colak, A. Hepbasli, A review of heat pump drying: Part 1-Systems, models and studies, Energy Conversion and Management 50 (2009) 2180-2186.

[8] C.S. Kiang and C.K. Jon, Heat pump drying systems: Handbook of Industrial Drying, Third Edition, Taylor and Francis Group, LLC, 1104-1130. 